\title{
Level Adoption of Feed and Organic Fertilizer Technology Based on By Products of Oil Palm Plantation Industry in Lamandau District, Central Kalimantan
}

\author{
Bambang Ngaji Utomo ${ }^{1}$, Ermin Widjaja ${ }^{2}$, Bambang Suharyanto ${ }^{3}$, Yaumil Putri Erlambang ${ }^{4}$, \\ Mohammad Sofyan ${ }^{5}$ \\ ${ }^{1)}$ Indonesian Research Institute for Veterinary Science \\ ${ }^{2)}$ Indonesian Center for Agricultural Technology Assessment and Development \\ ${ }^{3)}$ The Assessment Institute for Agricultural Technology of Central Kalimantan \\ 4) Business Shcool Bogor Agricultural University \\ ${ }^{5)}$ The STIAMI Institute of Social Sciences and Management \\ Correspondent: bng.utomo2004@gmail.com
}

Submitted : September 25, 2020 Revised : October 17, 2020 Published : October 31, 2020

\begin{abstract}
The main problem of livestock raising is feed, for that reason, the government issued a policy about integrated livestock farming with plants/plantations especially oil palm which has the potential to produce feed resources which was abundant, inexpensive, continuous and does not compete with human needs. The activity was carried out in Lamandau District, Central Kalimantan Province. The objective of the research is to look at the level of adoption of complete feed technology from the by-products of the oil palm plantation industry and organic fertilizer in order to initiate the activities of palm oil - cattle integration. A total of 10 farmer groups, 3 individuals and 1 Livestock Breeding Center of Agriculture services were becoming cooperators. The business activities of cooperator were including animal husbandry, horticultural crop farming and oil palm plantations. The assessment of the level of adoption is done through interviews, Focus Group Discussions (FGD) and field monitoring, which are classified into 3 criteria, namely low $(0.0$ $33.3 \%)$, moderate $(33.4-66.7 \%)$ and high $(66.8$ - 100\%). Introduction of technology and accompaniment activities were carried out for 3 years. The FGD activities involved various stakeholders such as the Regional Government, PBS of Palm Oil, Banking, and Farmer Groups. Direct practice is done for farmer group learning. The results of this study showed that in the first year only 1 farmer group adopted feed and organic fertilizer technology. The second year the level of adoption of cattle feed was $33.33 \%$ with the range production of 5-20 tons/month, solid organic fertilizer $33.33 \%$ with the ring production of 3-20 tons/month and liquid organic fertilizer (biourine) $33.33 \%$ with the range production of 1,000-4,000 liters/month. The third year the adoption level of cattle feed is $100 \%$ with the range production of $1-20$ tons/month, $100 \%$ solid organic fertilizer with the range production of 1-20 tons/month and 33.33\% liquid organic fertilizer with the range production of 1,000-4,000 liters/month. The conclusion is the adoption of feed technology was greater, followed by organic fertilizer and finally liquid fertilizer technology. This is related to how important is its use in the field. Commitment of local government and PBS of palm oil is needed to help easily and continuously obtain feed and fertilizers materials of palm oil mill byproduct and facilitating marketing of their products.
\end{abstract}

Key words: Adoption of technology, farmer groups, Complete feed, organic fertilizer, oil palm

\section{INTRODUCTION}

Feed is still a problem in livestock farming activities. Therefore the government issued a policy with an integrated approach between livestock and plants / plantations, mainly with oil palm plantations. This is due to the potential for feed resources provided by the byproduct of the 
Level Adoption of Feed and Organic Fertilizer Technology Based on By Products of Oil Palm Plantation Industry in Lamandau District, Central Kalimantan

Utomo, Widjaja, Suharyanto, Erlambang, \& Sofyan

oil palm plantation industry is abundant, inexpensive, continuous and does not compete with human needs. Some types of waste that have potential as animal feed are solid oil palm and palm kernel meal (BIS) (Utomo and Widjaja, 2004; Widjaja et al., 2005; Widjaja and Utomo, 2006; Utomo and Widjaja, 2012; Widjaja and Utomo, 2014).

Beef cattle population in Lamandau District was reported 3,956 with the most population in Bulik District 1,172 (29.63\%), second in Sematu Jaya District 915 (23.13\%) and the smallest population in Batangkawa District 155 tails (3.92\%) (BPS Lamandau, 2018). Requires alternative animal feed resources because forage (grass) is relatively difficult in the dry land of Lamandau District.

At present the commodity of palm oil becomes excellent because the type of land in Lamandau District is very suitable for oil palm plantations (Pemda Lamandau, 2018). Oil palm plantations in Lamandau District are spread across 7 districts with a total plantation area (smallholders + PBS of Oil Palm) of 175,480.46 Ha and with production of 288,856.76 tons (BPS Lamandau, 2018; BAPPEDA Lamandau, 2018).

Based on information from various sources and BPS reports (2017) there are 16 oil palm plantation companies operating in Lamandau District and the results of field monitoring at least 3 palm oil mills (PKS) that produce solid palm oil that have been utilized by farmer groups, namely PT. Gemaraksa Mekarsari (GM), PT. First Lamandau Timber International (FLTI) and PT. Sawit Mahardika Graha (SMG). Especially for PT. Gemaraksa Mekarsari produces 80-100 tons of solid palm oil per day (Syarif, 2019).

If the average of PT. Gemaraksa Mekarsari produces 90 tons/day, can meet the needs of cattle feed in number of 21.333 heads/day (If solid is given $1.5 \%$ of cattle body weight with an average body weight of $250 \mathrm{~kg} / \mathrm{head}$ ). Add more the other 2 factories which also produce solid oil palm. Animal feed forage in the per hectare oil palm plantation area can hold 1 head of cattle (PPKS, 2013), if 25\% of the total area of oil palm plantations in Lamandau District is integrated with cattle can accommodate around 43,870 head of cattle. Add more the available oil palm fronds of $7.2 \mathrm{~kg} /$ day $/$ ha (Widjaja et al., 2016), if the cattle feed needs are 10\% of body weight (assuming $250 \mathrm{~kg}$ ), then the availability of the oil palm fronds can meet 0.2 heads /day/ha, so that the potential for oil palm plantations alone can meet the needs of cattle feed is 1.2 heads / ha. If only $25 \%$ of the total area of oil palm plantations in Lamandau District can be integrated with cattle, it can accommodate of 52,644 heads. Thus by utilizing the byproducts of PKS (1 PKS) namely solid oil palm and the byproducts of oil palm plantations (forage between plants and oil palm fronds), the Lamandau District has the potential to develop as many as 73,977 head of cattle throughout the year (Widjaja et al., 2016) . Another potential feed resource is palm kernel cake (BIS). In the District of Lamandau, BIS was produced by PKS of PT. FITL. Nutritional content of BIS is better than solid oil palm (Widjaja and Utomo, 2016). This extraordinary potential has not been maximally utilized due to the lack of technological information to the farmers' community.

The purpose of this study is to disseminate low-cost of complete feed technology based on by-products of the oil palm plantation industry and organic fertilizer as an initiation of oil palmcow integration activities by farmer groups in Lamandau District.

\section{METHODS}

The activity was carried out in Lamandau District, Central Kalimantan Province. The location of the activities is close to the palm oil Mill (PKS). The activity is focused on the Pandau Makmur Farmer Group, where the livestock industry activities have begun to run by utilizing the 
Level Adoption of Feed and Organic Fertilizer Technology Based on By Products of Oil Palm Plantation Industry in Lamandau District, Central Kalimantan

Utomo, Widjaja, Suharyanto, Erlambang, \& Sofyan

byproduct of the oil palm plantation industry as animal feed, as well as the activities of organic fertilizer production have also been running. Based on the above considerations, the location is made as INTI (Center of Excellence), where other farmer groups can learn and practice directly of cattle farming activities, the process of making complete feed and organic fertilizer.

The material consists of a cage, feed material and organic fertilizer and equipment provided by the Pandau Makmur of Farmer Group, namely cattle (108 animals), solid oil palm (80 tons), fiber (80 tons), (faeces 200 tons), cattle cages, a place for feed processing, a place for processing solid and liquid organic fertilizers, chopper machine, feed mixer, cage equipment (hoe, shovel, rope, arko, wheelbarrow).

A total of 10 farmer groups in Lamandau Regency, each member of the farmer group consists of 25-30 people, 3 individuals and 1 UPT of the Lamandau District Agriculture Office conducting cattle breeding activities as a downstream object of a complete feed technology based on the byproducts of the oil palm plantation industry and organic fertilizer.

The technology downstream process was carried out for 3 years through FGD activities, training and mentoring of farmer groups. The activity involved Researchers from the Indonesian Agricultural Research and Development Agency and extension agent of local SKPD. Technical guidance (Bimtek) and practice are carried out at the location of Pandau Makmur Farmers Group, with consideration that participants can directly participate in the practice of providing feed materials, formulation and processing of feed, making solid and liquid organic fertilizer and can directly see the performance of cattle given the feed of the introduction of technology.

The FGD was held at the beginning of each year for 3 years, which was directly led by the Head of the Agriculture Office of Lamandau District, by involving other stakeholders such as PT. Gema Reksa, BRI Bank of Lamandau District Branch, Kalteng Bank of Lamandau District Branch, Extensions in the District of Lamandau, Heads and representatives of Farmer Groups in 8 Districts (Bulik, Sematu Jaya, Mentobi Raya, Bulik Timur, Delang, Batangkawa, Lamandau, and Belantikan Raya). The FGD was conducted to find out the problem, the progress of the development of the activity and also to capture the commitment of the relevant stakeholders to support the activity, especially from the oil palm plantation company. After the FGD continued with Bimtek and direct practice of prosessing complete feed based on the oil palm plantation industry and organic fertilizer (solid and liquid).

Assistance is carried out until transfer of technology can truly be applied by farmer groups. Assistance and guidance is carried out at the location of the activities of each farmer group. The process of implementing mentoring / coaching activities is carried out by monitoring both directly by visiting the location or indirectly through communication through Social Media to find out the development of activities and problems encountered.

The data collected consists of primary data and secondary data. Primary data in the form of information on the characteristics of respondents and information on the adoption / application of complete animal feed technology and organic fertilizer taken through interviews and direct observation in the field. While secondary data in the form of desk studies include information on the general condition of the region and other data related to research activities.

Data entered in the form of data matrices, analyzed descriptively, and presented in tabular form. While the adoption rate was assessed by classifying three criteria: low ( $0.0-33.3 \%)$, moderate (33.4 - 66.7\%) and high (66.8 - 100\%) (Rondom et al., 2012). 
Level Adoption of Feed and Organic Fertilizer Technology Based on By Products of Oil Palm Plantation Industry in Lamandau District, Central Kalimantan

Utomo, Widjaja, Suharyanto, Erlambang, \& Sofyan

\section{RESULTS AND DISCUSSION}

\section{Group of Farmers profile}

In general the profile of the farmer groups used by respondents in this research activity is presented in Table 1. In general, the head of the farmer group is still in the young category, with an age range of 30-50 years and the average of 42 years being a productive age (Zainal and Chris , 1991). Furthermore Zainal and Chris (1991) said that the age below 20 years is an age that has not been productive and can be categorized as school age, while the age above 59 years the productivity point has passed the normal point and will decline with age.

The average of cattle ownership are 8 - 150 heads and 4 - 250 hectares of oil palm plantations. There are two farmer groups that are pioneering palm-cattle integration activities, namely the Pandau Makmur Farmer Group and the Mitra Tani Sejahtera Farmer Group. However, the application of the technology still needs coaching.

Table 1.

The profile of farmer groups and individual cooperators in Lamandau District.

\begin{tabular}{|c|c|c|c|c|c|c|}
\hline No & $\begin{array}{l}\text { The Name of } \\
\text { Farmer Group }\end{array}$ & $\begin{array}{c}\text { The name of } \\
\text { Head }\end{array}$ & $\begin{array}{l}\text { The Age } \\
\text { (years) }\end{array}$ & $\begin{array}{l}\text { Education and } \\
\text { experience of } \\
\text { raising cattle }\end{array}$ & $\begin{array}{l}\text { Number } \\
\text { of cattle } \\
\text { (heads) }\end{array}$ & $\begin{array}{l}\text { Palm oil } \\
\text { area } \\
(\mathrm{Ha})\end{array}$ \\
\hline 1. & Pandau Makmur & Marukan & 50 & S3 (>5 years) & 150 & 250 \\
\hline 2. & Tani Subur & Sutiyana & 45 & SLTA ( $>5$ years) & 200 & 800 \\
\hline 3. & $\begin{array}{ll}\text { Mitra } & \text { Tani } \\
\text { Sejahtera } & \end{array}$ & Sofyan & & SLTA ( $>5$ years) & 60 & 25 \\
\hline 4. & Karya Bersama & $\begin{array}{l}\text { Gusti Zulkifli } \\
\text { Iskandar }\end{array}$ & 40 & SLTA ( $>5$ years) & 10 & 4 \\
\hline 5. & Agro Sejahtera & Sudamin & 39 & SLTA ( $>5$ years) & 12 & 40 \\
\hline 6. & Individu & Hendra & 45 & $\mathrm{~S} 1(<5$ years $)$ & 10 & 84 \\
\hline 7. & Putra Mangkaba & Asmadi & 37 & SLTA ( $>5$ years) & 8 & 4 \\
\hline 8. & Brahma Jaya & Suharta & 47 & SLTA ( $>5$ years) & 67 & 40 \\
\hline 9. & Lembu Jaya & Yayan & 41 & SLTA ( $>5$ years) & 25 & 30 \\
\hline 10. & Maju Bersama & $\begin{array}{l}\text { Gusti } \\
\text { Budiansyah }\end{array}$ & 30 & SLTA ( $>5$ years) & 50 & 25 \\
\hline 11. & Individu & Wajib & 42 & SLTA ( $>5$ years) & 15 & 10 \\
\hline 12. & Individu & Sugito & 46 & SLTA ( $>5$ years) & 10 & 4 \\
\hline 13. & $\begin{array}{lr}\text { Livestock } & \\
\text { breeding center } \\
\text { (UPT } \\
\text { Agriculture } \\
\text { Services, } \\
\text { Lamandau } \\
\text { District) }\end{array}$ & Sutirta & 42 & S1 (>5 years) & 30 & - \\
\hline
\end{tabular}

\section{Level of Adoption}

Adoption of technology is a mental process and behavioral change in the form of knowledge, attitudes and skills of farmers since they know until they decide to apply it (Fachrista and Sarwendah, 2014). The success of the application of technological innovation is influenced by one of the characteristics of farmers or farmer groups (Rondom et al., 2012), including the level of education (Burhansyah, 2014). The skills and knowledge obtained through livestock experience will also affect the level of technology adoption (Gustiani and Permadi, 2015). In this study, the average experience of raising cattle more than 5 years with education dominated by high school. The average age of the head of farmer groups in productive age (Zainal and Chris (1991) so that 
Level Adoption of Feed and Organic Fertilizer Technology Based on By Products of Oil Palm Plantation Industry in Lamandau District, Central Kalimantan

Utomo, Widjaja, Suharyanto, Erlambang, \& Sofyan

they are enthusiasm to know the technology and the opportunity to adopt of it is still high. The level of Adoption in this study can be seen in Tables 2, 3 and 4.

\section{Adoption of complete feed based on byproducts of palm oil industry}

The complete feed that was disseminated was recommended by Widjaja, et al. (2016) with the composition of feed formulations are presented in Table 2 .

Table 2.

Feed formulation based on byproducts of palm oil industry which was recommended by Widjaja et al. (2016).

\begin{tabular}{llc}
\hline No & Feed materials & Precentage \\
\hline 1. & Palm kernel mill (BIS) & 24,5 \\
2. & Solid & 30 \\
3. & Oil palm fronds & 43 \\
4. & Urea & 0,1 \\
5. & Molases & 2 \\
6. & Premix & 0,3 \\
7. & Fermentor & 0,1 \\
\hline & Total & 100,00 \\
\hline & Nutrient content & \\
\hline 1. & PK & 13,48 \\
2. & SK & 23,00 \\
3. & LK & 3,59 \\
4. & TDN & 66,00 \\
5. & Price $(\mathrm{Rp})$ & 912 \\
\hline
\end{tabular}

The formulation of complete feed mentioned above results in daily body weight gain (PBBH) $0.9 \mathrm{~kg} /$ day and has been applied and developed on a higher number of livestock which was 145 heads in the Pandau Makmur Farmer Group on Brahman Cross bulls. Bali cattle owned by UPT of the Department of Agriculture, Lamandau District, in number of 27 heads were given additional feed in the form of solid oil palm instead of complete feed, which originally was 0.2 $\mathrm{kg} / \mathrm{head} /$ day, increasing to $0.7 \mathrm{~kg} /$ head / day (Widjaja et al. , 2016). The UPT was only adopted its solid oil palm as feed supplement because of the unavailability of its feed processing equipment. A complete feed formulation was also adopted by the Farmer Group of Tani Subur which was applied to 15 males Balinese cattle. So that complete feed technology has been applied to 187 heads of cattle. The results of the study was strengthening confidence of farmer groups to adopt the technology. Adoption will be carried out if they are very confident of the benefits and losses arising from the implementation of the new technology.

The development of byproducts of palm oil industry as the main feed for cattle has been adopted by several farmer groups and has increased from year to year (Table 3).

Table 3.

The development of the adoption of feed based on palm oil plantation industry in Lamandau District

The adoption of cattle feed based on palm oil plantation industry

\begin{tabular}{|c|c|c|c|}
\hline & Condition in 2015 & Condition in 2016 & Condition in 2017 \\
\hline \multirow[t]{6}{*}{1.} & Production actors: & Production actors: & Production actors \\
\hline & 1. Farmer group of & 1. Farmer group of Pandau & 1. Farmer group of Pandau Makmur \\
\hline & Pandau Makmur & Makmur & UPT of Agriculture Services \\
\hline & & 2. UPT of Agriculture & 3. Farmer group of Tani Subur \\
\hline & & Services & 4. Farmer group of Mitra Tani \\
\hline & & $\begin{array}{l}\text { 3. Farmer group of Tani } \\
\text { Subur }\end{array}$ & $\begin{array}{l}\text { Sejahtera } \\
\text { 5. Farmer group of Karya Bersama }\end{array}$ \\
\hline
\end{tabular}




\begin{tabular}{|c|c|c|c|}
\hline & & $\begin{array}{l}\text { 4. Farmer group of Mitra } \\
\text { Tani Sejahtera }\end{array}$ & $\begin{array}{l}\text { 6. Farmer group of Agro Sejahtera } \\
\text { 7. Hendra (Individual) } \\
\text { 8. Farmer group of Putra Mangkaba } \\
\text { 9. Farmer group of Brahma Jaya } \\
\text { 10. Farmer group of Lembu Jaya } \\
\text { 11. Farmer group of Maju Bersama } \\
\text { 12. Wajib (Individual) } \\
\text { 13. Gito (Individual) }\end{array}$ \\
\hline 2. & $\begin{array}{l}\text { Scale of production: } \\
\text { 1. Farmer group of } \\
\text { Pandau Makmur: } 10 \\
\text { tons/month } \\
\text { (complete feed) }\end{array}$ & $\begin{array}{l}\text { Scale of production: } \\
\text { 1. Farmer group of Pandau } \\
\text { Makmur: } 20 \text { ton/bulan } \\
\text { (complete feed) } \\
\text { 2. UPT of Agriculture } \\
\text { Services: } 5 \text { tons/month } \\
\text { (complete feed), } \\
\text { Purchase Mixer and } \\
\text { Sreder, } \\
\text { APBD budget of } 150 \\
\text { million } \\
\text { Farmer group of Mitra } \\
\text { Tani Sejahtera: } 10 \\
\text { tons/month (complete } \\
\text { feed) }\end{array}$ & $\begin{array}{l}\text { Scale of production: } \\
\text { 1. Farmer group of Pandau } \\
\text { Makmur: } 20 \text { tons / bulan } \\
\text { (complete feed) } \\
\text { 2. UPT of Agriculture Services: } 5 \\
\text { tons/bulan (complete feed) } \\
\text { 3. Farmer group of Tani Subur: } 75 \\
\text { tons/month (complete feed) } \\
\text { 4. Farmer group of Mitra Tani } \\
\text { Sejahtera: } 5 \text { tons/month } \\
\text { (complete feed) } \\
\text { 5. Farmer group of Karya Bersama: } \\
\text { Supplementation of solid palm oil } \\
1 \text { ton/month } \\
\text { F. Farmer group of Agro Sejahtera: } \\
\text { Supplementation of solid palm oil } \\
2 \text { tons/month } \\
\text { Individu Hendra: } \\
\text { Supplementation of solid palm oil } \\
1 \text { ton/month } \\
\text { 8. Farmer group of Brahma Jaya: } 5 \\
\text { tons/month (complete feed) } \\
\text { 9. Farmer group of Putra } \\
\text { Mangkaba: Supplementation of } \\
\text { solid palm oil } 1 \text { ton/month } \\
\text { 10. Farmer group of Lembu Jaya: } \\
\text { Supplementation of solid palm oil } \\
3 \text { tons/month } \\
\text { 11. Farmer group of Maju Bersama: } \\
\text { Supplementation of solid palm oil } \\
7 \text { tons/month } \\
\text { 13. Gupplementation of solid palm oil } \\
\text { Supplementation of solid palm oil } \\
\text { 13itononth }\end{array}$ \\
\hline 3. & $\begin{array}{l}\text { Commercialization: } \\
\text { 1. Farmer group of } \\
\text { Pandau Makmur: } \\
\text { haven't sold yet }\end{array}$ & $\begin{array}{l}\text { Commercialization: } \\
\text { Not all, } \\
\text { To meet their own needs }\end{array}$ & $\begin{array}{l}\text { Commercialization: } \\
\text { Not all, } \\
\text { To meet their own needs }\end{array}$ \\
\hline
\end{tabular}

Animal feed formulation technology from Widjaja et al. (2016) was adopted in full by the Pandau Makmur Farmers Group, Mitra Tani Sejahtera Farmers Group, Brahma Jaya Farmers Group and Tani Subur Farmers Group. Other farmer groups only adopt one of their feed 
Level Adoption of Feed and Organic Fertilizer Technology Based on By Products of Oil Palm Plantation Industry in Lamandau District, Central Kalimantan

Utomo, Widjaja, Suharyanto, Erlambang, \& Sofyan

ingredients, namely solid oil palm. This is because they do not have the equipment for processing a complete feed which was based on byproducts of palm oil industry.

Nevertheless, palm oil has very high potential for animal feed, even if given singly, it can increase PBBH in PO cattle by $0.77 \mathrm{~kg} / \mathrm{head} /$ day and in Madura cattle, $0.56 \mathrm{~kg} / \mathrm{head} /$ day (Utomo and Widjaja, 2004). So that although only part of the feed material is adopted, it can increase the efficiency of livestock farming (Widjaja and Utomo, 2006).

\section{The adoption of solid organic fertilizer}

Solid organic fertilizer is made by using waste from cattle, that was dung mixed with palm oil mill industry waste (PKS). The composition of materials for making organic solid fertilizer is cattle dung $30.0 \%$; solid palm oil $30.0 \%$; fiber fruit juice: $30.0 \%$; ash: $5.0 \%$; microbes: $0.1 \%$; calk: $4.9 \%$. The analysis results of nutrient content of solid organic fertilizers according to SNI standards 19-7030-2004, several elements have been met according to the criteria (Widjaja et al., 2016).

The introduction of the technology solid organic fertilizer processing began to be developed and adopted since it was introduced at the beginning of this study and has increased the number of farmer groups that have adopted from year to year (Table 4).

Table 4.

The level of technology adoption of solid organic fertilizer in Lamandau District.

\begin{tabular}{|c|c|c|c|}
\hline & \multicolumn{3}{|c|}{ The adoption of solid organic fertilizer technology } \\
\hline & Condition in 2015 & Condition in 2016 & Condition in 2017 \\
\hline 1. & $\begin{array}{l}\text { Production actors: } \\
\text { 1. Farmer group of } \\
\text { Pandau Makmur }\end{array}$ & $\begin{array}{l}\text { Production actors: } \\
\text { 1. Farmer group of Pandau } \\
\text { Makmur } \\
\text { 2. UPT of Agriculture } \\
\text { Services } \\
\text { 3. Farmer group of Agro } \\
\text { Sejahtera } \\
\text { 4. Farmer group of Mitra } \\
\text { Tani Sejahtera }\end{array}$ & $\begin{array}{l}\text { Production actors: } \\
\text { 1. Farmer group of Pandau } \\
\text { Makmur } \\
\text { 2. UPT of Agriculture Services } \\
\text { 3. Farmer group of Tani Subur } \\
\text { 4. Farmer group of Mitra Tani } \\
\text { Sejahtera } \\
\text { 5. Farmer group of Karya } \\
\text { Bersama } \\
\text { 6. Farmer group of Agro } \\
\text { Sejahtera } \\
\text { 7. Farmer group of Putra } \\
\text { Mangkaba } \\
\text { 8. Farmer group of Brahma Jaya } \\
\text { 9. Farmer group of Lembu Jaya } \\
\text { 10. Farmer group of Maju } \\
\text { Bersama } \\
\text { 11. Wajib (individual) } \\
\text { 12. Gito (Individual) }\end{array}$ \\
\hline 2. & $\begin{array}{l}\text { Scale of production: } \\
\text { 1. Farmer group of } \\
\text { Pandau Makmur: } 5 \\
\text { tons/month }\end{array}$ & $\begin{array}{l}\text { Scale of production: } \\
\text { 1. Farmer group of Pandau } \\
\text { Makmur: } 20 \\
\text { tons/month } \\
\text { 2. UPT of Agriculture } \\
\text { Services: } 3 \text { tons / month } \\
\text { 3. Farmer group of Agro } \\
\text { Sejahtera: } 6 \text { tons } \\
\text { /month } \\
\text { 4. Farmer group of Mitra } \\
\text { Tani Sejahtera: } 15 \\
\text { tons/month }\end{array}$ & $\begin{array}{l}\text { Scale of production: } \\
\text { 1. Farmer group of Pandau } \\
\text { Makmur: } 20 \text { tons/month } \\
\text { 2. UPT of Agriculture Services: } 3 \\
\text { tons/month } \\
\text { 3. Farmer group of Tani Subur: } 90 \\
\text { tons/month } \\
\text { 4. Farmer group of Mitra Tani } \\
\text { Sejahtera: } 15 \text { tons/month } \\
\text { 5. Farmer group of Karya Bersama: } \\
1 \text { ton/month }\end{array}$ \\
\hline
\end{tabular}




\section{Commercialization:}

1. Farmer group of Pandau Makmur: haven't sold yet

\section{Commercialization:}

1. Farmer group of Pandau Makmur: on sale 5 ton/month, for their selves: 15 tons/month

2. UPT of Agriculture Services: on sale 1,5 tons/month, for their selves: 1,5 tons/month

3. Farmer group of Agro Sejahtera: on sale 4 tons/month, for their selves 2 tons/month
6. Farmer group of Agro Sejahtera: 6 tons/month

7. Farmer group of Putra Mangkaba: 1 ton/month

8. Farmer group of Brahma Jaya: 10 tons/month

9. Farmer group of Lembu Jaya: 5 tons/month

10. Farmer group of Maju Bersama: 8 tons/month

11. Wajib (Individual): 2 tons/ month

12. Gito (Individual): 1 ton/ month

\section{Commercialization:}

1. UPT of Agriculture Services: on sale 1,5 tons/month, for their selves: 1,5 tons/month

2. Farmer group of Agro Sejahtera: on sale 4 tons/month, for their selves 2 tons/month

3. Farmer group of Mitra Tani Sejahtera: depending on consumer demand

4. Others for their selves

\section{The adoption of liquid organic fertilizer (bio urine)}

The process of production liquid organic fertilizer (bio urine) which was recommended by Widjaja et al. (2016) refers to Guntoro (2006). The quality of liquid organic fertilizer which was produced is compared with the minimum standard requirements for liquid fertilizer based on the Minimum Technical Requirements of Organic Fertilizers and Soil Enhancers (SK Mentan No 28/Permentan/SR.130/B/2009), generally it was met with the criteria, except C organic which still lower than the standard requirements (Widjaja et al., 2019).

The level of adoption of technology liquid organic fertilizer processing is not as much as the adoption of technology solid organic fertilizer processing, as presented in Table 5.

Table 5.

The level of technology adoption of liquid organic fertilizer in Lamandau District.

The adoption of liquid organic fertilizer technology (Biourine)

Condition in 2015

1. Production actors:

1. Farmer group of Pandau

Makmur

$$
\text { Condition in } 2016
$$

\section{Production actors:}

1. Farmer group of Pandau Makmur

2. UPT of Agriculture Services

3. Farmer group of Tani Subur

4. Farmer group of Mitra Tani Sejahtera
2. Scale of production: Scale of production: (ltr/month):

1. Farmer group of Pandau

\section{Condition in 2017}

\section{Production actors:}

1. Farmer group of Pandau Makmur

2. UPT of Agriculture Services

3. Farmer group of Tani Subur

4. Farmer group of Mitra Tani Sejahtera

5. Farmer group of Agro Sejahtera
Scale of production: (ltr/month)

1. Farmer group of Pandau Makmur: 4.000 liters 
Level Adoption of Feed and Organic Fertilizer Technology Based on By Products of Oil Palm Plantation Industry in Lamandau District, Central Kalimantan

Utomo, Widjaja, Suharyanto, Erlambang, \& Sofyan

\begin{tabular}{|c|c|c|c|}
\hline & $\begin{array}{l}\text { Makmur: } 1000 \\
\text { liters }\end{array}$ & $\begin{array}{l}\text { 1. Farmer group of } \\
\text { Pandau Makmur: } \\
4.000 \text { liters } \\
\text { 2. UPT of Agriculture } \\
\text { Services: } 1.000 \text { liters } \\
\text { 3. Farmer group of Tani } \\
\text { Subur: } 12.000 \text { liters } \\
\text { 4. Farmer group of Mitra } \\
\text { Tani Sejahtera: } 1000 \\
\text { liters }\end{array}$ & $\begin{array}{l}\text { 2. UPT of Agriculture Services: } \\
1.000 \text { liters } \\
\text { 3. Farmer group of Tani Subur: } \\
12.000 \text { liters } \\
\text { 4. Farmer group of Mitra Tani } \\
\text { Sejahtera: } 1000 \text { liters } \\
\text { 5. Farmer group of Agro Sejahtera: } \\
600 \text { litters }\end{array}$ \\
\hline 3. & $\begin{array}{l}\text { Commercialization: } \\
\text { 1. Farmer group } \\
\text { of Pandau } \\
\text { Makmur: } \\
\text { haven't }\end{array}$ & $\begin{array}{l}\text { Commercialization: } \\
\text { 1. UPT of Agriculture } \\
\text { Services: on sale } 120 \\
\text { liters, for their selves: } \\
880 \text { liters } \\
\text { 2. Farmer group of Tani } \\
\text { Subur: } 12.000 \text { liters } \\
\text { 3. Farmer group of Mitra } \\
\text { Tani Sejahtera: free } \\
\text { promotion } 500 \text { liters, } \\
\text { for their selves } 500 \\
\text { liters }\end{array}$ & $\begin{array}{l}\text { Commercialization: } \\
\text { 1. Farmer group of Tani Subur: on } \\
\text { sale } 12.000 \text { liters } \\
\text { 2. Other farmer group have difficulty } \\
\text { selling }\end{array}$ \\
\hline
\end{tabular}

Within three years the adoption level of animal feed and organic fertilizer is presented in Figure 1. The adoption level of feed product was up to $100 \%$, for solid organic fertilizer was $92.3 \%$ while for liquid organic fertilizer was $38.5 \%$. Cattle feed is the highest interest because it is a solution to overcome the production costs of feed which reaches around 70\% (Mathius, 2008; Tangendjaja, 2009). Feed raw materials are also abundantly available in the around of the location and it was able to increase the ADG of cattle compared to existing conditions.

Such as the case, the utilization of organic fertilizer has been also proven in the field to be able to increase production and income (Hutabarat, 2002; Siswati and Nizar, 2012; Purba, 2016; Widjaja and Utomo, 2019). The results of the application of solid and liquid organic fertilizer in one of the cooperating farmers groups, in the 5 mounds of chilli plants ( 1 mound length was 30 meters with 100 chilli trees) are able to provide 600 thousand income per day (Utomo, 2019). This is one example of why organic fertilizer is still routinely produced by farmer groups.

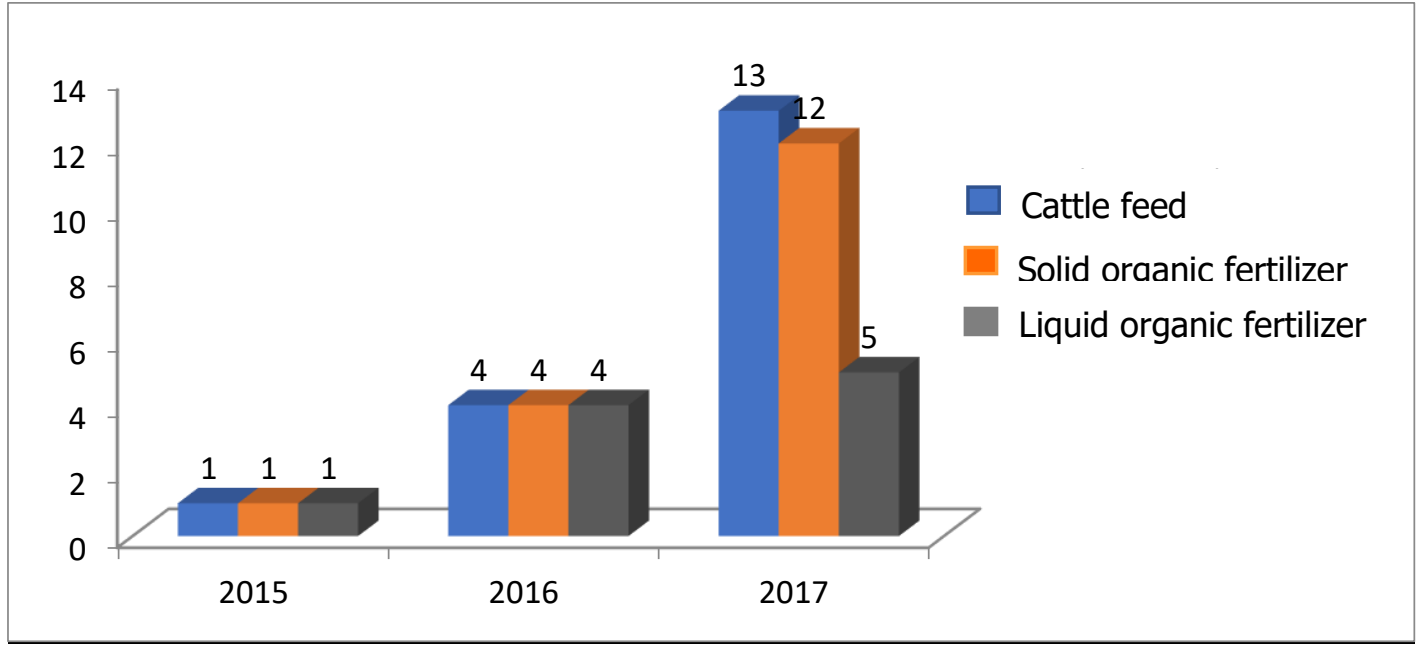


Level Adoption of Feed and Organic Fertilizer Technology Based on By Products of Oil Palm Plantation Industry in Lamandau District, Central Kalimantan

Utomo, Widjaja, Suharyanto, Erlambang, \& Sofyan

Figure 1. The progress of the adopting of feed and organic fertilizer technology in Lamandau District.

\section{The factors affecting the acceleration of technology adoption}

Technology will be easily accepted by target farmers, if the technology is in accordance with the needs to be able to solve the problems faced by farmers. Based on observations during the process of technology adoption there are several important things that affect the process of technology adoption, namely:

1. There is a pilot introduction of technology in the Center of Excellent as a place for practice and direct application;

2. Supporting Government of Lamandau District, starting from the Regent and the Head of Agriculture Office, namely facilitating meetings with the factory as a provider of raw materials and at the same time asking the factory to be able to supply raw materials of feed such as solid oil palm and BIS. They were also facilitated meetings with Banks, related to Credit Schemes that can be used by Farmer Groups;

3. Technical guidance followed by direct practice in the field, make easier the introduction of technology was absorbed by participants

4. Mentoring farmer groups, both directly and indirectly, enables the technology was rapidly adopted

5. For farmer groups that do not have complete feed processing machines, by farmer groups that can produce the product, they are given finished feed to be bartered with cattle dung.

Some of the factors mentioned above were in line with the opinion of Soekartawi (2005). The mature technology cannot necessarily be adopted by farmer groups although technically they have mastered it.

The problem is not all farmer groups available equipment for processing animal feed or organic fertilizer. So there are some farmer groups who cannot adopt technology completely. Several farmer groups bartered livestock manure with complete feed based on by-products of oil palm plantation industry from other farmer groups, especially the Farmer Group of Pande Makmur. Another problem is the difficulty in marketing products, both feed and organic fertilizer. Most of the products are used by farmer groups themselves. The need intervention of local government in helping to market these products. This can be overcome by linking regional programs such as the development of horticultural crops and food plants that require organic fertilizer. Thus it will be stimulating the emergence of the organic fertilizer industry in the region by farmer groups.

\section{CONCLUSION}

The combination of practice and accompaniment activities as well as strong commitment from the local government caused the adoption of technology of animal feed and organic fertilizer which can be adopted step by step by farmer groups in Lamandau District.

Real results in the field about utilizing the by-products of the oil palm plantation industry both for animal feed and solid organic fertilizers increase the adoption level of technology.

Fertilizer marketing is still a problem, thus affecting the production capability of each farmer group. 
Level Adoption of Feed and Organic Fertilizer Technology Based on By Products of Oil Palm Plantation Industry in Lamandau District, Central Kalimantan

Utomo, Widjaja, Suharyanto, Erlambang, \& Sofyan

The regional government should be supporting the activities that have the potential to drive the economy of the region, primarily through the assistance of equipment and material access to the palm oil mills (PKS).

The regional government can facilitate the marketing of its main products, organic fertilizer, it was produced by farmer groups. This can be related with the Regional Government's program on the development of food crops or horticulture that requires organic fertilizer. It also can be lined up with PBS of palm oil to be able to utilize organic fertilizer products from the farmer groups.

\section{ACKNOWLEDGEMENT}

Thank very much you to the Indonesian Agricultural Research and Development Agency through the KP4S program which has funded this research activity for 3 years. The Regent of Lamandau District, the head of Agriculture Office of Lamandau District and his staff who have assisted and facilitated activities in the field.

\section{REFERENCES}

BAPPEDA Lamandau. (2018). Selayang pandang Kabupaten Lamandau 2018. Nangabulik BPS Lamandau. (2018a). Kabupaten Lamandau dalam angka 2018. Nangabulik BPS Lamandau. (2018b). Statistik daerah kabupaten Lamandau 2018. Nangabulik

Burhansyah, R. (2014). Faktor-Faktor Yang Mempengaruhi Adopsi Inovasi Pertanian Pada Gapoktan Puap Dan Non Puap Di Kalimantan Barat (Studi Kasus: Kabupaten Pontianak Dan Landak). Informatika Pertanian 23(1) : 65 - 74. doi:10.21082/ip.v23n1.2014.p65-74

Fachrista, I.A. \& Sarwendah, M. (2014). Persepsi dan Tingkat Adopsi Petani Terhadap Inovasi Teknologi Pengelolaan Tanaman Terpadu Padi Sawah. Agriekonomika 3(1): 1-10. Retrieved from https://journal.trunojoyo.ac.id/agriekonomika/article/view/435/406

Guntoro, S. (2006). Leaftet "Teknik Produksi dan Aplikasi Pupuk Organik Cair dari Limbah Ternak". Kerjasama Balai Pengkajian Teknologi Pertanian Bali dengan Bappeda Provinsi Bali.

Gustiani, E. \& Permad, K. (2015). Tingkat Adopsi Peternak Terhadap Teknologi Pengolahan Tongkol Jagung Pakan Ternak Di Majalengka Livestock Adoption on Processing Technology of Animal Feed Corn Cob in Majalengka. Agros 17(1): 88-94. Retrieved from http://e-journal.janabadra.ac.id/index.php/JA/article/view/128/106

Mathius, I W. (2008). Pengembangan sapi potong berbasis industry kelapa sawit. Pengembangan Inovasi Pertanian 1(2): 206-224. Retrieved from http://203.190.37.42/publikasi/ip013083.pdf

PPKS (Pusat Penelitian Kelapa Sawit). (2012). Sawit, sapi, kompor dan energi. Materi disajikan pada Roundtable Discussion (RTD) 8 Juni 2012. Pusat Penelitian dan Pengembangan Peternakan, Bogor.

PPKS. (2013). Sawit, sapi, kompor dan energi. Materi disajikan pada Roundtable Discussion (RTD) 8 Juni 2012. Puslitbang Peternakan, Bogor.

Purba, R. (2016). Kajian Penggunaan Pupuk Organik pada Sistem Usahatani Bawang Merah di Serang Banten. Planta Tropika Journal of Agro Science Vol 4 No 1 / Februari 2016: 1 6. doi:0.18196/pt.2016.049.1-6. Doi:10.18196/pt.2016.049.1-6

Soekartawi. (2005). Prinsip Dasar Komunikasi Pertanian. Jakarta (ID): UI Press. 
Level Adoption of Feed and Organic Fertilizer Technology Based on By Products of Oil Palm Plantation Industry

in Lamandau District, Central Kalimantan

Utomo, Widjaja, Suharyanto, Erlambang, \& Sofyan

Siswati, L. \& Nizar, R. (2012). Model Pertanian Terpadu Tanaman Hortikultura dan Ternak Sapi untuk Meningkatkan Pendapatan Petani. Jurnal Peternakan Indonesia 14(2): 379-384. doi:10.25077/jpi.14.2.379-384.2012

Tangendjaja. (2009). Teknologi pakan dalam menunjang industry peternakan di Indonesia. Pengembangan Inovasi Pertanian 2(3): 192-207.

Utomo, B.N. \& Widjaja, E. (2004). Limbah padat pengolahan minyak sawit sebagai sumber nutrisi ternak ruminansia. Jurnal Penelitian dan Pengembangan Pertanian 23(1): 22-28. Retrived from http://203.190.37.42/publikasi/p3231044.pdf

Utomo, B.N. \& Widjaja, E. 2012. Pengembangan Sapi Potong Berbasis Industri Perkebunan Kelapa Sawit. J. Litbang Pert. 31(4): 153-161. Retrieved frfom http://ejurnal.litbang.pertanian.go.id/index.php/ippp/article/view/1028/898

Utomo, B.N. 2019. Sistem Integrasi Sawit-Sapi di Kelompok Tani di Kabupaten Lamandau. Laporan Perjalanan Dinas. BB Litvet. Bogor

Widjaja, E., Utomo, B.N., \& Sarwani, M. (2005). Inovasi teknologi mendukung sistem integrasi ternak dengan kelapa sawit di Kalimantan Tengah. Prosiding Lokakarya Pengembangan Sistem Integrasi Kelapa Sawit-Sapi. Banjarbaru Kalimantan Selatan, 22-23 Agustus 2005. Puslitbangnak.

Widjaja, E. \& Utomo, B.N. (2006). Prospek penggemukan sapi potong di sekitar pabrik kelapa sawit di Kalimantan Tengah. Prosiding Seminar Teknologi Peternakan dan Veteirner. Puslitbang Peternakan. Bogor. Hlm 110-115.

Widjaja, E., \& Utomo, B.N. (2014). Pertanian Bio-Industri Berbasis Kelapa Sawit-Ternak (Perjalanan Panjang Sebuah Inovasi). IAARD Press. Badan Penelitian dan Pengembangan Pertanian.

Widjaja, E. \& Utomo, B.N. (2016). Laporan Perjalanan Dinas. KKP3S Bioindustri Sawit-Sapi di Kabupaten Lamandau. BBP2TP. Bogor.

Widjaja, E., B.N. Utomo, B. Haryanto, A. Firmansyah, T. Rahmawati, Sunarto \& E. Purba. (2016). Model pertanian Bio-Industri Berbasis Integrasi Sawit-Sapi di Kabupaten Lamandau. Kalimantan Tengah. Laporan akhir kegiatan KKP3SL 2015. Badan Penelitian dan Pengembangan Pertanian.

Widjaja, E. \& Utomo, B.N. (2019). Kegiatan Usaha Tani Terpadu Sapi, Hortikultura Dan Embung Di Lahan Lahan Kering Kabupaten Lamandau Kalimantan Tengah (Studi Kasus Di Kecamatan Bulik). Malakah disampaikan pada kongres ke-8 dan simposium ke-9 Perhimpunan Meteorologi Pertanian Indonesia (PERHIMPI). IPB Convention Center. Bogor 